\title{
Social Media and Fake News in Nigeria: A Speech Act Analysis of WhatsApp Messages on Coronavirus
}

\section{Godwin Ayigbo Owojecho}

Department of English, Institute of Education, University of Abuja, Nigeria.

\begin{tabular}{llllll}
\hline Received: 29.12.2020 & • & Accepted: 01.04.2021 & • & Published: 30.06.2021 & • Final Version: 30.06.2021 \\
\hline
\end{tabular}

\begin{abstract}
The evolution of social media has opened a new vista in digital communication across the world, Nigeria inclusive. Since the confirmation of the index case of Coronavirus in Nigeria, a lot of news on the subject which are largely considered by the World Health Organization to be false, had gone viral on the social media space. This study essentially examines some of those messages on WhatsApp that were circulated across Nigeria. Five WhatsApp messages collected between March - June, 2020 were analysed using the framework of Austin's Speech Acts with insights from the Conversational Maxims of Grice's Cooperative Principles. The main objective of this analysis is to unravel the communicative effects of language. Findings show that the writers of those WhatsApp messages carefully manipulate some linguistic features to make such messages perform some illocutionary acts as well as trigger some perlocutionary moves in the minds of the readers. This buttresses the fact that language is used to achieve both linguistic and non linguistic aims.
\end{abstract}

Keywords: Coronavirus, Covid-19, WhatAspp, Social Media, Digital Communication.

\section{Introduction}

In the wake of the revolutionary stride in digital and technological innovation in the world today, social communication and interaction have become very easy to the people. The advent of social media as a channel of communication has further widened the width in the dissemination of messages and information to a wider number of people. Social media is a term that has been described as websites and applications developed and designed to ease the effective transmission and dissemination of online contents (Hudson, 2019). It is a conglomeration of new digital media channels through which people get connected and share information on personal, general as well as global issues. Since the innovation of digital communication and its attendant increase in social interaction, a good number of social media platforms have evolved. Some of them include WhatsApp, Facebook, Twitter, Instagram, Google+, Pinterest, Snapchat and Youtube.

\subsection{Social Media and the Proliferation of Fake News in Nigeria}

As easy and simple as social media is to human interaction and socialization, it has equally, and perhaps, sadly enabled countless unhealthy practices and attitudes by many careless users. One of such ills is the proliferation of fake news via its many channels. Fake news is a kind of news content containing a deliberate misinformation and fabrication peddled around social media platforms and, sometimes, in the traditional mainstream media (print and electronic) (Wikipedia, n.d).

This kind of news, often found in some prominent news websites, is fabricated news presented as factual and real. 
In Nigeria, and indeed the entire world, WhatsApp has become a popular social media platform that has served as a medium through which fake news perpetrates. Launched in 2009, WhatsApp is a world most text and voice messaging application that allows users to freely message one another using mobile as well as desktop devices. The usefulness of WhatsApp towards the enlightenment of people in Nigeria cannot be over emphasized. Through WhatsApp, vital information is passed on to people within a very short time. As useful as WhatsApp is to people, it is however used as a veritable tool to peddle fake news. The crux of this research is the analysis of messages on Coronavirus considered as fake news peddled on WhatsApp in Nigeria. To properly undertake this, the principle of speech act is employed.

Coronavirus disease, also called Covid-19, is an infectious disease caused by "a newly discovered Coronavirus" (WHO, 2020). The virus is believed to have emerged in Wuhan, China in December, 2019 and spread across many countries in the world within a short space of time. Some of the symptoms include fever, muscle aches, headache, sore throat, difficulty in breathing, loss of taste and smell, diarrhea and cough. Since the confirmation of the index case of Covid-19 in Nigeria, a lot of messages had been circulated on WhatsApp by many users. Most of these messages border on issues of heath and various other issues which are purported to be fake news. This study attempts to analyze the act contained in such messages and the socio cultural impacts such messages have on Nigeria.

\subsection{Classification of Fake News on Social Media in Nigeria}

A close study of fake news on social media in Nigeria shows that they come in different forms with each serving the purpose the authors of such news want to portray. Some of these are discussed below.

\section{Rumour}

Rumour is described as "unverified information statements that circulate about topics that people perceive as important; arise in situations of ambiguity, threat, or potential threat; and are used by people attempting to make sense or to manage risk" Di Fonzo (1994). Rumours thrive well in a situation where people lack access to the truth about information that is of general concern. Though different in some ways, rumours and fake news are two phenomena that can hardly be detached. This is because people often describe pieces of news which, in most cases, get confirmed as fake or remain unverified as rumours (Kwon, et al., 2013). In the same way, some pieces of information which are obviously true, most times end up being described as rumours when the truth remains hidden. In Nigeria, most fake news circulates on social media as mere rumours. Since the confirmation of Covid-19 index case in Nigeria in March, 2020, the social media, especially WhatsApp has been inundated with rumour mills. These rumours include some myths surrounding prevention and cure of Covid-19.

\section{Enlightenment/Warning}

It is a fact worthy of note that not all fabricated news could be dangerous for human consumption as some sections of society may see it. A good number of fake news in Nigeria is meant to enlighten or warn people from engaging in tasks considered not healthy. Sometimes, it comes with some advice or direction and commits people to carry out an action considered good and helpful. 
Below is a message that went viral on WhatsApp in Nigeria which, though adjudged by the Ministry of Health as fake news, is considered enlightening and helpful:

This is to inform us all that the $p H$ for corona virus varies from 5.5 to 8.5 . *RESEARCH: JOURNAL OF VIROLOGY, APRIL 1991, PAGE 1916* All we need to do, to *beat corona virus*, we need to take more of an alkaline foods that are *above the above pH level of the Virus*. Some of which are:- *Lemon - 9.9pH*-*Lime - 8.2pH*-*Avocado - 15.6pH*_ *Garlic 13.2pH*-*Mango - 8.7pH*-*Tangerine - 8.5pH*-*Pineapple - 12.7pH*_*Dandelion 22.7pH*-*Orange 9.2pH* Your Good Health Is our Priority.

\section{Sarcasm/ Humour}

As serious as the issue of fake news is, some authors of such news on social media are only out to make fun of certain prevailing situations. Messages under this category are very funny and meant to douse a tensed atmosphere. This kind of message attracts a good followership from people because it is believed by many that the only thing that is left to make an angry Nigerian happy and forget the agony of things falling apart in the country is comedy. This gave Nigerian comedians much prominence in the entertainment industry. The message below is technically false but obviously funny:

*Breaking News!*

A new virus has been found in Nigeria, discovered on Saturday, 28th of March, 2020, it is called *Hunger Virus* $(* H U N V I D-20 *)$, it is caused by the failure of governments of Nigeria to provide some measures to address the hunger associated with lock down for over $70 \%$ of the populace.

*Symptoms:*

The symptoms are so numerous. It starts with mild thinking, but could later generate to severe thinking, then headache, stomach rumbling, children crying of severe stomach bite, worms in the belly will start protesting, ulcer rates increases 400\% within 24 hours. It kills faster than COVID 19; within 5 days, about 40\% of the population may be gone.

*Target class: *

The worst part of it is that it affects only the poor masses, as the government officials have gathered enough for themselves and their family. Though it is not contagious but everyone that falls within that class will experience it.

*Implications/Resultants:*

Resultant effects of the Huvid20 is that the citizens may engage in burglary, locked shops will be major targets, increased rate of stealing just to avoid premature death, hence guard your pot of food well.

The above message is obviously a mockery of government's insensitivity to the plights of the poor and helpless masses in Nigeria who deserved to be given palliatives at the time the entire nation was on lockdown. Though very funny, the text carries a reasonable message.

\section{Incisiveness}

Incisive comments are always known to arouse tension and panic in any volatile society. The message below which was widely circulated in Nigeria at the period of Covid-19 pandemic is capable of inciting the Nigerian people and indeed the entire world against China.

*Let's be careful please*

In Spain: over 640,000 \#Covid19 testing kits from China didn't work...Czech: 150,000 kits from China tested positive. Ukraine: 250,000 kits from China tested positive. Turkey: 500,000 kits tested positive. Netherlands: 600,000 masks from China were returned. China proudly killing the world....Please my fellow Nigerians.... Stay 
away from all the Coronavirus kits sent from China government through their agent called Jack Ma... It already arrived MMIA since Monday through Ethiopian airline.. and I heard it was moved to Abuja for distribution... Who knows the fact.. But please don't get close to them in the name of God you serve. I beg all of you...

\author{
Their mission is to reduce the population of Nigerians and still make money from it. Those kits from China \\ are the real Coronavirus.
} Thanks...

\title{
Trial of Innovation
}

Due to advancement in technology, many innovations have come up in the world of Information Technology. The evolution of social media is a creation of this advancement. Some fake news on social media platforms and sites are published by some upcoming IT professionals with the aim of testing how popular their innovation could be. During the period of Covid-19 pandemic in Nigeria, a lot of messages about alleged government palliatives were circulated all over social media. Most of the messages came with accompanying web links for people to click so they could qualify for the palliatives. The obvious truth is that no government palliatives for everyone existed at the time those messages went viral. The fake messages were merely a creation of some IT "boys" meant to direct people to their web pages or blogs just for them to have a huge traffic on those sites. Again, some of the links provided do not exist while others are meant to defraud unsuspecting individuals. The news below fits into this category:

*FG* has finally approved and have started giving out free_N30,000_Relief Funds to each citizen

Below is how to claim and get your account credited instantly as I have just did now

http://ngr.freeinternetz.com/

*Note*: You can only claim and get credited once and it's also limited so get yours now Instantly.

\subsection{Usefulness of the Study}

The significant roles played by WhatsApp messages in either shaping or shattering the peaceful atmosphere, unity and trust in Nigeria cannot be overemphasized. It is an established fact that messages and news on Coronavirus pandemic peddled around on WhatsApp have so much to do with the implicit and explicit intentions of the writers or initiators of such messages. The present study is an attempt to unravel the illocutionary act, the perlocutionary move of the senders of fake messages as well as the level of observance of Grice's Conversational Maxims of such messages on the WhatsApp platform. The usefulness of this study lies in the fact that it would enlighten WhatsApp users on the real motive of the initiators of forwarded messages on WhatsApp.

\section{Literature Review}

The subject of social media as well as fake news, though relatively new, is no longer fresh in both the public and academic discourse in Nigeria. Researchers have made good attempts to discuss the topic and how far it has impacted on the peaceful coexistence of Nigerians.

Auwal (2018) examines the use of social media and its implications on the peaceful coexistence in Nigeria. Using Critical Discourse Analysis method, he analyses the tone of Facebook users' comments on Biafra agitations and the Arewa youths' quit notice to Igbo residents in the North. The study concludes that social media heightens divisive tendencies in Nigeria as exemplified by the user's comments which exposes regional and religious sentiments in Nigeria. The similarity between this study and the present study is in the fact that both analyses texts on social media in Nigeria. The point of divergence is the methods of analysis employed in the studies. While this study analyses 
data using the method of Critical Discourse Analysis, the present study uses Speech Act principles to analyse data.

Considering the fact that fake news go much viral on social media, Ogbette et al (2019) examine its impacts in Nigeria and how its construction in language affects the unity and peaceful coexistence of the people. The study shows that fake news come about as a result of several reasons which include the need for relevance, poor regularization of the cyber space and a host of other ulterior motives of the publishers of those news. They conclude that there should be proper confirmation and authentication of the sources of information peddled on social media.

The present study also examines the impact of fake news on the people but dwells much on the linguistic manipulation of the writers of the fake news analysed.

Dentith (2017) argues that fake news is merely a feature of political discourse. According to him, fake news, which he also calls Alternative Facts, is, in most cases, a creation of political manipulation expressed insincerely by some political actors. He however suggests that one possible solution to the issues of fake news is to change the terms of the debate to give room for ethical concern in public epistemology. Unlike this study, the present study demonstrates the obvious reality of fake news and its perlocutionary effects on the readers of such news.

In a similar vein, Dancu (2017) questions the whole idea of fake news. Going by this argument, fake news is seen as a complicated concept with many facets. He believes that the idea of fake news has ideological and political relevance. He suggests a restoration of people's confidence in the media, without which every piece of news will be seen as fake. The present study posits that fake news does not only portray ideological sentiments but also national sentiments.

Taiwo, et al (2017) examine the discursive issues that surround ideological and identity leanings in the posting of rumours on social media. They conclude that rumours in Nigeria thrive through the discursive constructions of Negative Other and Positive Self polarity. The present study, to a great extent, agrees with this study. However, as similar as this study is to the present study, the slight difference is the focus of the studies.

The work focuses on rumours in Nigeria, while the present study, on the other hand, focuses on fake news in Nigeria.

\section{Methodology}

This study dwells wholly on data drawn from Covid-19 related news, circulated on WhatsApp messenger by many Nigerians during the period of this research (March - June, 2020). Five different messages which are obviously seen to be described as fake news are purposively selected from Whats App and analysed. A qualitative analysis of the data was done using Austin's notion of Speech Acts with insights from Grice's Conversational Maxims.

\section{Theoretical Framework}

This study is essentially a pragmatic exercise and grounded on Austin's (1962) Speech Acts Theory with insights from the Conversational Maxims of Grice's (1975) Cooperative Principles. Austin's Speech Acts Theory can be traced to a lecture he delivered in Oxford in the years 1952-1954 with the title "Words and

deeds" (Collavin, 2011). Austin's Speech Acts Theory, as modified by Searle (1969), outlines about five categories of illocutionary acts based on their corresponding perlocutionary effects on the 
audience. They are as follows: Assertives- which includes an act that represents a state of affairs. E.g. stating, claiming, hypothesizing, describing, telling, insisting, suggesting, asserting, or swearing that something is the case; Directives -an act for getting the addressee to do something. E.g. ordering, commanding, warning, daring, defying, challenging, etc.; Commissives- an illocutionary act for getting the speaker, i.e. the one performing the speech act, to do something. Using this act, the speaker commits himself or herself to a course of (future) action. E.g. promising, pledging, threatening, intending, and vowing to do or to refrain from doing something; Expressives- an act that expresses the mental state of the speaker about an event presumed to be true. Here, the speaker expresses an attitude to or about a state of affairs. E.g. congratulating, thanking, appreciating, deploring, condoling, welcoming, apologizing, detesting, etc.; Declaratives- an act that brings into existence the state of affairs to which it refers. E.g. blessing, firing, baptizing, bidding, passing a sentence, excommunicating, etc.

Insights from Grice's Conversational Maxims, woven around the notion of Cooperative Principles, provides a sound platform for this study. Grice's Conversational Maxims are a form of implicatures which explain the connections between utterances and what is understood from them. Grice (1975) proposes that participants in a conversation obey a general 'cooperative principle' which should naturally manifest when a communicative conversation is on. He says: "Make your conversational contribution such as is required, at the stage at which it occurs, by the accepted purpose or direction of the talk exchange in which you are engaged."(45). He outlines four maxims that guide his theory. These maxims include maxims of quantity (make your contribution as informative as is required for the current purposes of the exchange, do not make your contribution more informative than is required); Maxims of quality (do not say what you believe to be false, do not say that for which you lack adequate evidence); Maxim of Relation (be relevant); Maxims of manner (avoid obscurity of expression, avoid ambiguity, be brief, be orderly). It is, no doubt, a fact that in certain cases, speakers in talk exchange may either purposefully or accidentally fail to fulfill a maxim in various ways (Grice, 1975). Such speakers may violate, flout, infringe, suspend or simply opt out of a maxim. In this study, there shall be a discussion on the quality of observance of the maxims by the authors of WhatsApp messages on Covid-19 who do that with the aim of achieving certain aims.

\section{Data Analysis/ Discussion}

This study is basically a pragmatic exercise. Therefore, analysis of data as well as the discussion and findings are based on Austin's notion of Speech Acts as well as Grice's Conversational Maxims. The WhatsApp messages (news) for analysis shall, henceforth in the analysis, be called extracts. Each extract shall be analysed on the basis of the illocutionary act type performed, the perlocutionary effects on the audience and the quality of observance of Grice's Conversational Maxims.

\section{Extract 1}

The vaccine has just arrived Nigerian airport few hours ago from China.

Please send this information to our lovely ones at home, advise them to stay away from this deadly materials.

\begin{tabular}{|l|l|l|}
\hline $\begin{array}{l}\text { Act Type } \\
\text { (Illocution) }\end{array}$ & Perlocution & $\begin{array}{l}\text { Maxim } \\
\text { (Observance) }\end{array}$ \\
\hline $\begin{array}{l}\text { Directives } \\
\text { (warning) }\end{array}$ & Instigating, inciting & $\begin{array}{l}\text { Quality } \\
\text { (flouting) }\end{array}$ \\
\hline
\end{tabular}

\section{Analysis and Discussion}


The extract above is one WhatsApp message that went viral at a time only a few cases of Covid19 were just confirmed in Nigeria. At this time, it was obviously too early to get the vaccine or cure for the virus of this magnitude. According to the World Health Organization, there is usually no known vaccine for a disease that is new; it takes about a year for a vaccine to be developed to prevent such a disease from spreading. The message in the above extract is therefore not true because it is not backed up with facts. However, this information was taken in by many Nigerians because Covid19, being a pandemic that began in China, is believed to be a China-created disease. Again, many also believed that Covid-19 was created by some world powerful occult groups considered to be the Anti-Christ with the aim of inserting some chips on people's bodies in form of vaccines. These are all rumours that really do not have verifiable proofs but believed by many as true.

The illocutionary act performed in the message is directive. The writer directs the reader that the message be sent to "our lovely ones" and warns his or her audience not to have anything to do with the so-called vaccine which is described as "deadly." The message equally has some perlocutionary effects on the reader. The reader is instigated and incited against China and anything that comes from China.

For this message to have a strong effect in the minds of the reader, the writer intentionally flouts Grice's quality maxim. According to Grice, a speaker flouts the quality maxim when he or she says something which is considered to be blatantly untrue. In the case of the extract above, the message contained is obviously not true because at the time of conducting this research, no vaccine was actually brought to Nigeria from China for the prevention of Covid-19.

\section{Extract 2}

They'll call you that you're entitled to the N20,000 from FGN.

Please do not send your BVN. And do not click any link. Do not also give them any code sent to your phone. Someone just lost N125k now. Don't say I didn't tell you.

*Be warned $^{*}$

\begin{tabular}{|l|l|l|}
\hline $\begin{array}{l}\text { Act Type } \\
\text { (Illocution) }\end{array}$ & Perlocution & $\begin{array}{l}\text { Maxim } \\
\text { (Observance) }\end{array}$ \\
\hline $\begin{array}{l}\text { Directives } \\
\text { (warning) }\end{array}$ & Enlightening, convincing & $\begin{array}{l}\text { Quantity } \\
\text { (flouting) }\end{array}$ \\
\hline
\end{tabular}

\section{Analysis and Discussion}

Covid-19 pandemic no doubt brought about the spread of fake news and false information in Nigeria. The extract above conveys the danger of such information. In an attempt to control the spread of Coronavirus, the Federal Government of Nigeria, at some points announced total and phased lockdown of the nation. At those times, messages bordering on palliatives allegedly promised by the government inundated the social media space, especially WhatsApp, mandating unsuspecting individuals to click certain internet links and send sensitive bank details like the Bank Verification Number (BVN) to benefit from the so-called Covid-19 relief fund. At the same time, some well meaning Nigerians took to their social media pages warning people to ignore such information. The information above is one of such endavours meant to enlighten the general public and warn them against falling preys to internet scammers who obviously author such fake news.

The act performed by this message is that of directives. The writer warns the reader to desist from exposing sensitive details to fraudsters. This message is obviously convincing due to its inherent perlocutionary effects. The writer achieves this effect by giving an instance of someone 
who was previously duped of N125,000 by scammers. By giving an instance and quoting an exact amount of money the said victim lost to fraudsters, the writer aims at convincing the reader to believe what is being said.

The writer unostentatiously breaches Grice's quantity maxim. Quantity maxim demands that one makes a contribution as informative as is required. In this manner, any contribution that is more informative than is required is an outright breach of this maxim. The writer's information in the above extract is more informative than is required and it is a breach of Grice's maxim of quantity. The inclusion of the statements: "Don't say I didn't tell you" and "Be warned" are more or less redundant. The underlying message of the statement would ordinarily be passed even with the absence of those additional comments.

Extract 3

NIGERIAN GOVERNMENT MOVE INTO ACTION!

*All* Nigerian Citizens are Entitled to 100GB of Data *to stay* *at**Home* To counter the COVID 19 Case. We offer you 100GB of free internet connection. * All Nigerian Citizens are entitled to free Internet Connection to stay at home safely and enjoy the internet in a bid to control the spread of COVID 19. The free internet package is available to everyone starting from Tuesday 24 March 2020.* Congratulations!

CLICK TO APPLY ==> https://bit.ly/COVID19_FG_100GB_FREE_DATA

\begin{tabular}{|l|l|l|}
\hline $\begin{array}{l}\text { Act Type } \\
\text { (Illocution) }\end{array}$ & Perlocution & $\begin{array}{l}\text { Maxim } \\
\text { (Observance) }\end{array}$ \\
\hline $\begin{array}{l}\text { Assertives } \\
\text { (claiming); }\end{array}$ & Reassuring, enlightening & $\begin{array}{l}\text { Quantity } \\
\text { (flouting) }\end{array}$ \\
$\begin{array}{l}\text { Directives } \\
\text { (ordering) }\end{array}$ & & \\
\hline
\end{tabular}

\section{Analysis and Discussion}

The message above conveys information which was later discovered to be fake news. This message was circulated on WhatsApp all over the nation and it got the attention of many Nigerians. The fake news was spread at a time when the majority of people were asked to stay at home in order to control the spread of Covid-19. Also, this message got an undue attention because at that time, organizations and businesses, including a few telecommunication network providers, were giving palliatives in kind and cash to their esteemed customers. Many Nigerians were lured into clicking the given link with the hope of getting free internet data.

The act performed by the message is both assertives and directives. The writer of the message claims that it is true that $100 \mathrm{~GB}$ of free data is being given by a network provider which is not stated. At the end of the message, the writer directs his or her audience to perform an action - to click on the given link in order to claim the said 100GB free data.

Quantity maxim is flouted by the writer in two ways. First, more information is supplied than that which is required. There is a case of undue repetition of the same ideas. For example, the ideas conveyed in the following sentences are the same: "Nigerian Citizens are entitled to 100GB of Data to stay at home." "Nigerian Citizens are entitled to free Internet Connection to stay at home." Also, vital information that would have enhanced a better understanding of the message is either intentionally of inadvertently omitted. The message would have sunk well if the writer had 
mentioned the name of the particular network provider giving the offer. The major telecommunication network providers in Nigeria include Glo, Airtel, 9mobile and MTN but none of them were mentioned in the text; a case of outright flouting of Grice's maxim of quantity. In this case, little information than what is required is supplied. However, the message is reassuring and enlightening. It is a type of information most Nigerians would want to get at that moment when Covid-19 had a serious economic impact on the people.

\section{Extract 4}

*Let's be careful please*

In Spain: over 640,000 \#Covid19 testing kits from China didn't work...

Czech: 150,000 kits from China tested positive.

Ukraine: 250,000 kits from China tested positive.

Turkey: 500,000 kits tested positive

Netherlands: 600,000 masks from China were returned.

China proudly killing the world....Please my fellow Nigerians.... Stay away from all the Coronavirus kits sent from China government through their agent called Jack Ma... It already arrived MMIA since Monday through Ethiopian airline.. and I heard it was moved to Abuja for distribution...

Who knows the fact.

But please don't get close to them in the name of God you serve. I beg all of you... Their mission is to reduce the population of Nigerians and still make money from it. Those kits from China are the real Coronavirus. Thanks...

\begin{tabular}{|l|l|l|}
\hline $\begin{array}{l}\text { Act Type } \\
\text { (Illocution) }\end{array}$ & Perlocution & $\begin{array}{l}\text { Maxim } \\
\text { (Observance) }\end{array}$ \\
\hline $\begin{array}{l}\text { Assertives } \\
\text { (claimimg); }\end{array}$ & Inciting, thought provoking & $\begin{array}{l}\text { Quality } \\
\text { (flouting) }\end{array}$ \\
$\begin{array}{l}\text { Directives } \\
\text { (warning) }\end{array}$ & & \\
\hline
\end{tabular}

\section{Analysis and Discussion}

The information contained in the extract above went viral on WhatsApp at the time Nigerian government was considering importing Covid-19 test kits from China. It was a time when many claimed that Covid-19 was created in China and spread to the whole world. This message is one of such claims. The message contains clear instances, accompanied with figures, where Chinese test kits failed. However, it is considered fake news because there is no verifiable proof to back it up as being true. This, in fact, is corroborated by the text itself considering the statement, "who knows the fact."

Fake news performs a lot of performative goals. One of such goals is the manipulation of the text receivers to believe and carry out an action which may either be to their benefit or detriment (Taiwo, et al, 2017). The text writer can achieve this aim by manipulating the language of the text. In this current text, the unknown writer makes a claim (an assertion) which is supported by figures and 
name. This is so to make the text receivers believe every bit of the news. Apart from making an assertion, the writer also linguistically manipulates the text to warn, as well as, direct the receivers to perform an action- to stay away from the text kits purportedly imported from China.

The perlocutionary motive of the writer, no doubt, is to incite the people against China. This is not surprising because it all happened at a time when people around the world, including prominent world leaders, believed that China had questions to answer concerning Covid-19.

On a careful look at this message, one would quickly question its authenticity. This is considered a breach of Grice's Conversational Maxim. The writer obviously flouts the maxim of quality by supplying information which is believed to be false and without adequate evidence.

\section{Extract 5}

SERIOUS EXCELLENT ADVICE by Japanese doctors treating Covid-19 cases. Everyone should ensure your mouth and throat is moist, never DRY. Take a few sips of water every 15 mins at least. WHY? Even if the viruses get into your mouth... drinking water or other liquids will WASH them down through your esophagus and into the stomach. Once there in the tummy.... your stomach ACID will kill all the viruses. If you don't drink enough water more regularly....the virus can enter your windpipes and into the LUNGS. That's very dangerous.

Please send and share with family, friends and every other about this! Take care everyone n may the world recover from corona virus soon. May all be well and happy. May Coronavirus not be your portion IJN.

\begin{tabular}{|l|l|l|}
\hline $\begin{array}{l}\text { Act Type } \\
\text { (Illocution) }\end{array}$ & Perlocution & $\begin{array}{l}\text { Maxim } \\
\text { (Observance) }\end{array}$ \\
\hline $\begin{array}{l}\text { Assertives } \\
\text { (claiming); }\end{array}$ & Enlightening, informative & $\begin{array}{l}\text { Quantity } \\
\text { (flouting) }\end{array}$ \\
$\begin{array}{l}\text { Directives } \\
\text { (ordering) }\end{array}$ & & \\
\hline
\end{tabular}

As informative as the message in the extract above could be, it is not considered altogether true by the relevant health authorities in Nigeria and the World Health Organisation. This message was widely circulated across Nigeria when Covid-19 cases were initially confirmed in many countries. At this time, the World Health Organisation warned vehemently against any form of self medication and observance of what they call "myths" about Covid-19. Therefore, any information about prevention and cure of Covid-19 (which could be true) that does not emanate from the World Health Organisation or the health authorities of nations is considered as fake news.

In this text, the writer makes a claim (an assertion) as well as gives a directive. The reader is made to believe that all the writer says about the prevention of Coronavirus is true; a fact not to be ignored if someone needs to be safe from the virus. The text also performs an illocutionary act of directing the reader to act on the message by forwarding it to friends and family members for them to stay enlightened and safe.

No doubt, the message contained in the text is quite enlightening and informative. Though considered as fake news, it however reveals a certain practice that must be imbibed by everyone to stay safe from Coronavirus. According to it, regular intake of water could prevent the virus. This is quite informative indeed but not verified during the period of this research.

Despite the fact that the text is informative, it however does not pass Grice's standard of Conversational Maxims. The writer of the text obviously flouts the maxim of quantity. The addition 
of redundant messages at the end of the text is considered more informative than is required and therefore a breach of quantity maxim.

\section{Conclusion}

The evolution of social media has no doubt enhanced digital communication in our technologically advanced world today. It has been discovered that WhatsApp, an aspect of social media, served as a powerful medium through which some fake news on Coronavirus circulated across Nigeria. This study analysed some forwarded messages on Coronavirus which were circulated on WhatsApp across Nigeria during the Coronavirus pandemic. Data were analysed using Austin's Speech Acts Theory with insights from Grice's Conversational Maxims. It has been discovered that the writers of those Whatsapp messages carefully manipulate some linguistic features to make such messages perform some illocutionary acts as well as trigger some perlocutionary moves in the minds of the readers. To achieve result, they intentionally flout quality and quantity maxims of Grice.

It is, no doubt, an established fact that language is not just for communication but a tool used to achieve certain aims by certain users. Therefore, the analysis carried out in this research will further enable other language researchers and individuals who are not linguists to pay much attention to the role of language in every communicative encounter.

\section{References}

[1] Austin, J. L. (1962). How to do things with words. Clarendon.

[2] Auwal, A. M. (2018). Social media and hate speech: Analysis of comments on Biafra agitation, Arewa Youths' ultimatum and their implications on peaceful coexistence in Nigeria. MCC, 2(1), 54-74.

[3] Collavin, E. (2011). Speech acts in Wolfram Bublitz and Neal R Norrick (eds), Foundations of pragmatics, Walter de Gruyter GmbH \& Co. KG, Berlin/Boston.

[4] Dancu, V.S. (2017). Fake news or fake concept? Sinteza - Review of Culture and Strategic Thinking, Cluj Napoca.

[5] Dentith, M. R. X. (2007). What makes 'fake news' 'fake' news. Retrieved from https://www.academia.edu/32699239/What_makes_fake_news_fake_news

[6] DiFonzo, N., B. P. \& R. R. (1994). Reining in Rumors. Organizational Dynamics, 47-62.

[7] Grice, P. (1975) "Logic and conversation" in A. P. Martinis (ed.). The philosophy of language, Oxford: OUP.

[8] Hudson, M. (1019). What is social media? Retrieved from https://www.thebalancesmb.com/what-is-socialmedia-2890301

[9] Kwon, S et al. (2013). Prominent features of rumor propagation in online social media. 2013 IEEE 13th International Conference on Data Mining. IEEE, 1103-1108.

[10] Ogbette, A.S., et al. (2019). Fake news in Nigeria: Causes, effects and management. Information and knowledge management, 9(2), 96-99. Doi: 10.7176/IKM

[11] Taiwo, R., Orevaoghene, A. \& Adebukunola, F. (2017). Social media and discursive construction of rumours in Nigeria. Ife studies in English Language, 13(1), 69-94.

[12] Wikipedia. (2020). Social Media. Retrieved from https://en.wikipedia.org/wiki/Social_media

[13] World Health Organisation. (2020). Coronavirus. Retrieved from https://www.who.int/health topics/Coronavirus\#tab=tab_1 